\title{
Loose Connections: Crime and Policing on the University Campus
}

\section{IAN GOMME}

University of Southern Colorado

\section{ANTHONY MICUCCl}

Memorial University of Newfoundland

\section{Abstract}

This paper reviews literature on campus crime and security. It reports the findings of a case study of an in-house security force servicing a large postsecondary institution located in central Canada. Limited data on campus crime in Canada and the U.S. indicate that it is neither as frequent nor as serious as media and other reports suggest. Primary data on the demographic characteristics of security officers combined with information on recruitment, training, mobility, and job content point to the existence of occupational segmentation within this sector. The findings also underscore the prevalence of a professional crime control-oriented form of security provision and are consistent with those of recent Canadian and American studies of campus crime and policing. The need for future research on issues concerning illegality and security on university campuses is highlighted and policy recommendations addressing the transition to a more community-oriented approach are outlined. 


\section{Résumé}

Les auteurs de cet article examinent la documentation concernant la criminalité et la sécurité sur les complexes universitaires et présentent les conclusions d'une étude de cas sur le service de sécurité interne d'un grand établissement d'enseignement postsecondaire du Canada central. Des données limitées relatives à la criminalité sur les campus d'universités canadiennes et américaines indiquent que les crimes commis n'y sont ni aussi fréquents ni aussi graves que ne le suggèrent les médias ou d'autres rapports. Les données brutes relatives aux caractéristiques démographiques des agents de sécurité, jumelées à l'information existante sur leur recrutement, leur formation, leur mobilité et la nature de leur travail, signalent l'existence d'une segmentation professionnelle dans ce secteur. Les conclusions soulignent également la prédominance d'une forme de services professionnels de sécurité visant la répression du crime et recoupent les conclusions d'études récentes menés au Canada et aux États-Unis sur la criminalité et le maintien de l'ordre dans les complexes universitaires. Enfin, l'étude insiste sur la nécessité d'effectuer d'autres recherches sur les questions concernant les actes illégaux et la sécurité sur les campus et présente certaines recommandations de principe visant à faciliter la transitions de l'approche actuelle vers une approche davantage axée sur la collectivité.

\section{Introduction}

The 1993 murder of a female student by cross-bow at the British Columbia Institute of Technology, the 1992 killings of four professors at Concordia University, and the 1989 homicides of 14 young women at the University of Montreal were intensively covered by the media and focused considerable attention on campus crime and security in this country. In addition, research into violence against university and college women, specifically the incidence of sexual assault and date rape, has also been widely publicized and has projected an image of the campus as a dangerous place particularly for female students (Dekeseredy \& Kelly, 1993, 1995; Donham, 1995; Lederman, 1993; Matthews, 1993; 
Morin, 1990; University Affairs, December 1995, March 1992, April 1992). While it is well known that the media focus on violence and ignore other non-violent and therefore less newsworthy criminal events, the attention paid to serious personal offenses nevertheless exerts a strong impact on concerned audiences (Belknap \& Erez, 1995; Sloan, 1994). The perception of crime as a serious campus problem is growing among faculty, staff, students and their parents (Bromley, 1995; Fisher \& Sloan, 1993) and especially among university administrators (Fernandez \& Lizotte, 1995; Sloan, 1994; Steenbarger \& Zimmer, 1992). In the United States, a bill requiring the reporting of campus crime, the Student Right-to-Know and Campus Security Act, was initially passed in 1990 and is now being revised and strengthened. Several colleges in that country have been successfully sued for failing to remedy conditions that were foreseeably criminogenic and that resulted in victimization (Smith, 1995). Universities in the U.S. are now including in their brochures descriptions of their crime (-free) profiles and their security operations (Knott, 1993).

Little is known about illegality, fear of crime, and policing on Canadian campuses for several reasons. First, data on campus crime in Canada are neither systematically collected nor disseminated. In the U.S., by contrast, the Student Right-to-Know and Campus Security Act (1990) requires universities to disclose not only their crime statistics but their security policies and programs as well. Second, Canadian campuses rarely constitute separate police jurisdictions with commensurately distinct official crime statistics. Third, Canadian campus security agencies themselves employ no standardized crime recording system (Brantingham \& Brantingham, 1994). Fourth, there have been few studies of campus crime and fear and their results remain largely unpublished. Surveys addressing student misconduct tend to be narrow in scope (drug and alcohol use, woman abuse) or, as Brantingham and Brantingham (1994) point out, are plagued by conceptual problems (see, for example, DeKeseredy \& Kelly, 1993, 1995; Fox, 1993; Gartner, 1993). Finally, there are no Canadian studies of campus policing. One early investigation of private security more generally (Freedman \& Stenning, 1977) 
limited itself to assessing the opinion of security directors on the granting of police powers to campus security personnel.

Research on campus crime, fear, and policing is important for several reasons. First, victimization can result in physical and psychological injury and property damage or loss. Universities wish to provide users with adequate protection through the design of appropriate and cost effective crime control measures. Second, failure to provide adequate protection may result in costly litigation by aggrieved parties. Third, perceptions of a campus as a dangerous place may erode the quality of academic and social life for students, faculty, and staff, as well as undermining a school's ability to attract and retain both clientele and personnel. Finally, campus crime prevention, crime control, and fear reduction strategies cannot be properly designed and effectively implemented in the absence of data on the degree and type of crime and fear and on the nature of the police or security response. Cost effective resource allocation is a particularly salient issue in times characterized by growing safety and security concerns, budget shrinkages, and pressures for organizational downsizing. As Brantingham and Brantingham (1994) note, prevention and control initiatives aimed at extremely rare events (violence) are likely to be costly, to generate fear, and to be ineffective at reducing crime.

This paper begins with an examination of why the campus environment may or may not be criminogenic. Key findings of American and Canadian research on campus victimization and fear of crime are then outlined. Using this crime profile as a counterpoint, the first Canadian study focussing exclusively on the organization and activities of a campus law enforcement agency is described. Data are presented concerning officers' backgrounds, experience, recruitment, training, mobility, and job content. The relevance of these findings is subsequently discussed in the context of occupational segmentation and its impact on the provision of security services that effectively address campus crime problems and other service needs. 


\section{Literature Review}

Universities are rather unique institutional contexts in that they resemble communities of various sizes, shapes, and compositions. Usually located within or adjacent to towns and cities, they serve as places of education, residence, recreation, commerce, and work for large numbers of people whose backgrounds, goals, and activities are diverse (Smith, 1988). Communities, to one degree or another, experience problems with victimization and fear of crime (Reiss, 1985; Sampson, 1995) and universities are no exception (Bordner \& Petersen, 1983; Fernandez \& Lizotte, 1995).

Some characteristics of university communities increase the risk of victimization and fear of crime while others lower it. First, universities are disproportionately populated by young people, under the age of 25 , who are comparatively unconcerned with their own security. One of the most durable findings in criminological research is that young people are over-represented in crime statistics both as perpetrators and as victims (Adler, Mueller, \& Laufer, 1996; Hirschi \& Gottfredson, 1983). Second, those who access university campuses and facilities are varied in their backgrounds and comparatively transient. Group cohesion and community attachment, factors known to reduce crime, are low. In addition, eccentric dress and behaviour on the part of students and faculty are greeted with high degrees of tolerance. Persons who themselves are legitimately on campus cannot be readily distinguished from those who are not (Sloan, Fisher, \& Wilkins, 1996). Third, campus grounds are park-like environments with 24 hour access often via public thoroughfares. Their boundaries are frequently indistinct, blending with surrounding communities to form "transitional zones" containing studentoriented housing and services. Not only are campuses open, they are comprised of large numbers of multi-purpose buildings (e.g., residences, classrooms, offices, laboratories, libraries, parking garages, sports complexes, food services, bars, retail outlets) which themselves contain very valuable property (e.g., laboratory equipment, audio-visual and computer technology, vehicles, consumer merchandise, information) (Richards, 1996). Fourth, universities provide residence and entertainment facilities for significant numbers of people, the majority of whom are young. Whether at home in residence or out at the campus bar, 
university students are well known for their high rates of alcohol consumption and for their use of prohibited drugs. Youth, diversity, transience, open access, concentrations of property, alcohol consumption, and illegal drug use increase a community's risks for heightened rates of predation and victimization by insiders and outsiders alike (Siegal \& Raymond, 1992; Sloan, Fisher, \& Wilkins, 1996).

Several countervailing factors, however, do lower the potential for crime on campus. The higher levels of education, elevated economic standing, and more intensive social commitment characteristic of university populations are inversely associated with crime (Gomme, 1993). Moreover, university campuses do not project the images of neglect commonly associated with criminal activity - run-down buildings, unkempt lawns, graffiti, broken lights, and dishevelled people (Skogan, 1990; Wilson \& Kelling, 1982). Well-manicured grounds and well-maintained buildings convey an aura of civility and order incongruent with high levels of law-breaking, victimization, and fear of crime (Sloan et al., 1996).

Recent research suggests that at least a third of students on U.S. campuses express concern over becoming the victim of crime (Smith \& Fossey, 1995). That the greatest concern expressed involves frequenting the campus at night and that women are more fearful than men (Fisher \& Nasar, 1992) are findings that reflect those of research on fear of crime more generally (Murphy \& Clairmont, 1990; Sacco \& Johnson, 1990; Statistics Canada, 1993).

Also consistent with criminological research more generally are the facts that levels of fear are much higher than levels of actual victimization (Moriarty \& Pelfrey, 1996) and that what crime does occur is very rarely violent (Brantingham, Mu, \& Verma, 1995). Victimization on American campuses comprises in the main property offenses such as burglary and petty theft (65\%-75\%) and vandalism (20\%) (Bromley, 1992; Knott, 1993; Ordovensky, 1990; Sloan, 1994; Stormer \& Senarath, 1992; Vito \& Holmes, 1994). Ordovensky, in a study of 494 American colleges and universities, estimates violent offending at only $6 \%$ while Vito and Holmes assess its occurrence at 1 in 1000 . Violent offending, while rare, is comprised of fights and assaults, sexual assaults, and 
robbery in descending order of frequency (Bausell, Bausell, \& Siegal, 1991). Evidence suggests, as well, that the vast majority of violent episodes are alcohol related (Siegal \& Raymond, 1992). While outsiders are frequently deemed responsible for crimes perpetrated on American campuses (Moriarty \& Pelfrey, 1996), research suggests that most illegalities are committed by registered students (Siegal \& Raymond, 1992).

The only social scientific study focussing on campus crime in Canada was conducted at Simon Fraser University in 1992-1993 (Brantingham \& Brantingham, 1994; Brantingham, Brantingham, \& Seagrave, 1995). Brantingham and Brantingham (1994) report that, whether recorded officially by university police or by the RCMP or whether documented through their victimization survey, the crime rate at SFU in 1992-93 was low. With respect to violent crime, official data indicate no homicides, no robberies, no sexual assaults, and very few common assaults. Theft and vandalism, both property crimes, comprised $80 \%$ of illegalities brought to the attention of campus police. Another common event requiring a response on the part of campus police involved reports of suspicious persons. These averaged two incidents per week.

Survey data also provide a picture of campus crime as both infrequent and minor. Only $14 \%$ of survey respondents indicated that they had been victimized by crime on the SFU campus during 1992-93. Ten percent were victims of theft and $4 \%$ had their property vandalized. About $1 / 2$ of $1 \%$ were the victims of an assault. No respondents were robbed or sexually assaulted. While $98 \%$ reported feeling safe on the campus during the day, about a third reported feeling unsafe at night. Night-time fear was considerably higher among women $(48 \%)$ than among men $(12 \%)$. The pattern of victimizations found by the survey is broadly consistent with the pattern of offenses shown in the campus security incident reports. Theft and vandalism dominate and crimes against the person are rare.

One problem highlighted by the SFU research is worthy of note. Brantingham and Brantingham (1994) report that neither students nor faculty took seriously internal security procedures. Not only did they fail to fasten doors and windows but they went so far as to disable locks and to intentionally leave doors open or ajar for extended periods of time. 
Brantingham and Brantingham underscore the risk potential associated with these practices and report that 5000 such incidents were detected by university police in a single year (1992-93).

While far from detailed, the picture of campus crime provided by both American and Canadian research differs from that projected by media reports and other sources. Campus crime appears infrequent, nonviolent, and involves property as opposed to personal offenses. Given these preliminary insights, questions remain about how university communities are policed, the implications of current police or security organization and procedure, and what, if any, measures should be adopted to improve the provision of security services on Canadian campuses.

\section{Method}

Between January and June 1989, data on an in-house unionized campus security force $(\mathrm{N}=36)$ were collected through 54 periods of sustained observation (involving mostly 12 hour shifts). Observation data were augmented by in-depth general and focussed interviews (ranging in duration from two to four hours) with all six administrators and the 30 uniformed officers. Night shifts (7:30 p.m.-7:30 a.m.) were over sampled on the assumption that more serious order maintenance and crime control problems would occur during the evening hours (Walker, 1992). Further information on personnel and organizational characteristics was obtained from student press reports, the union contract, and the force's Standard Operating Procedures Manual. Ten officers from both senior administration (3) and the lower ranks (7) contributed follow-up information between September 1989 and May 1991.

\section{Findings}

\section{Organization}

A Director and two Assistant Directors comprised the force's senior management. A Security Investigator, a Crime Prevention Officer, and a Student Security Coordinator managed the investigations, crime prevention, and student security units, respectively. Foot and motor vehicle 
patrols were undertaken by 21 Security Officers while four Senior Security Officers served as dispatchers. Communications and patrol tasks were administered by five Security Supervisors. The two campuses serviced comprised 44,000 full and part-time students, 1,232 full-time and 1,050 part-time faculty, and a support staff in excess of 5,000. The force, unlike its counterparts on many other Canadian campuses, did not possess the police powers inherent in special constable status.

\section{Age, Gender, and Education}

The force was primarily male (28 of 36 ) and middle-aged. Mean and median ages were 41 and 39 with a standard deviation of 15 years. While ages ranged from 21 to 65 , over a third (13 of 36) were in their 20 s and half were under 40 . The university recruited its first female officer in 1985 and over a fifth of the agency was comprised of women only four years later. A third of the force possessed postsecondary diplomas (10 with community college certificates and 2 with university degrees) while the remainder (23 of 35 ) had at least some high school training. Education levels were inversely related to age. Ten out of the 12 officers who were postsecondary graduates were under the age of 35 whereas 6 of the 7 respondents with only some high school were aged 55-65. Of the 10 officers with college certification, 8 had graduated from programs focussing on loss prevention or law enforcement.

\section{Experience}

The vast majority of campus officers possessed experience directly relevant to their current positions. Experience was categorized on the following dimensions: 1) policing only, 2) security only, and 3) policing and security. About one-quarter ( 8 of 35 ) of the force had been previously employed ( 3 to 36 years) by a Canadian, foreign, or military police agency. Of this group, two had been retained by more than one force. Those with previous police experience were found at all ranks. Four recently recruited administrators and two recently hired supervisors reported lengthy careers ( 13 to 36 years) as officers with either military or public police organizations. 
Previous private security experience with contract (8) or in-house (4) forces, or both (2) was reported by just under half of the force (14 of 35), all of whom were in the lower ranks. While experience ranged up to 15 years, the majority had less than 4 years of experience.

One-fifth of the force ( 7 of 35), all located in the lower ranks, reported combined police and security experience. This experience ranged extensively both in duration (up to 19 years in policing and up to 16 years in security work) and in rank. In addition, five comparatively young officers (mean age $=27$ ), all but one of whom were in the lower ranks, served as auxiliary police while simultaneously in the employ of the university's security force.

One-sixth of the force (6 of 35) lacked either police or security experience. Nonetheless, the "inexperienced" included two college graduates who had apprenticed with the force as part of their colleges' training programs. Furthermore, one officer had worked part-time as a member of the student security division prior to joining the force full-time. Thus, in only three cases were respondents totally devoid of any prior police or security experience.

\section{Recruitment and Job Choice}

In addition to high school accreditation, basic qualifications for all positions included: 1) demonstrable expertise in crime prevention, investigations, disaster preparedness, and physical security, and 2) previous police, military, or security experience (2-10 years depending on the position). Despite these official skill and experience requirements, five recent recruits gained entry to the lowest rank without the stipulated experience. Their completion of college programs in security or law enforcement was accepted as a substitute. Similarly, lengthy military experience was of pivotal importance in the appointment of two individuals to management positions despite their lacking the requisite postsecondary credentials.

Figuring prominently in officers' career trajectories were the "stepping-stone" and "second-career" mobility strategies. One-third (11 of 35) undertook their positions with the view that security work was a "stepping-stone" to a career in policing. Police aspirants tended to be 
young ( 8 under 26 years of age), better-educated ( 8 college certified in security or law enforcement), and concentrated in the lower ranks (10 of 11). Their intention, as the following remarks indicate, was to obtain suitable training and enforcement experience and later to cash in these human capital investments for positions with police agencies.

I'm using this [university security] job as a stepping-stone to a police force. I thought it would give me good, valuable training. I applied to the OPP [Ontario Provincial Police] three years ago and failed the one-mile run.

I have already applied to a police force and was rejected. This is not a career placement for me. It wouldn't bother me to spend a year here. I'm using this job as a stepping-stone to the police.

Five of the 8 persons who had put in long stints as police or military police officers perceived campus security work as a means of launching meaningful second careers. Four had faced limited advancement opportunities in their former occupations while simultaneously being afforded the occasion to retire at or near full pension well before age 65 .

\section{Training and Perceptions of Training}

Campus officers, at the time of the study, received no formal required pre-assignment training. A majority of officers (27 of 35) did, however, avail themselves of one or more in-service courses stressing the crime control and order maintenance elements of the police role. A defensive tactics course ( 20 officers) concentrated on combat capabilities while the Certified Protection Officer course (20 officers) emphasized methods of patrol, investigation techniques, legal powers, and report writing. In addition, security administrators were actively exploring the utility of training at least some junior officers as special constables. The core of the nine week special constable program offered at the provincial police college would have emphasized law enforcement issues and procedures such as criminal offenses, legal powers (arrest, search), crisis intervention, selfdefense, prisoner control, drug recognition, and traffic enforcement. 
In rare cases, specialized courses were offered for supervisors. Again, these courses were, for the most part, closely connected to the crime control and order maintenance aspects of the police role. They included rape awareness, emergency preparedness, bomb response, and defensive driving. While lectures in "service excellence," occupational health and safety, and computer programming were also available, they were viewed as less critical to the security enterprise.

Recruits acquired on-the-job training during their first three twelvehour shifts. Subsequently, they were left mostly to their own devices. Some work routines were mastered only after executing them on the job while others were learned through unofficial means such as self-instruction and informal socialization in the company of both security peers and police officers.

While the importance of loss prevention and order maintenance skills such as locating and resetting fire alarms, securing doors, and regulating traffic were recognized as important by both recruits and seasoned officers, it was the younger officers newer to the force who most heavily stressed the value of skills associated with crime control and order maintenance (arrest, interrogation, report writing, and collecting criminal record information from the police through the Canadian Police Information Centre). The high degree of importance placed by veterans on loss prevention directly reflected their view of this function as the primary purpose of security work.

Almost half the force (14 officers) emphasized the importance of police, auxiliary police, and college training. Five auxiliary police officers reported that their auxiliary training focussed on crime control and that it was augmented by on-the-job experience under the direction of seasoned police officers. Six security and law enforcement graduates stressed the utility of their college courses in investigations, criminal justice and corrections, photography as a tool for law enforcement, and loss prevention. They also reported that the substance of these courses was in turn reinforced by practical on-the-job experience in internships with security, police, or correctional agencies.

While administrators and veterans in the lower ranks were comparatively satisfied with their training, younger junior officers clearly were 
not. Due to their higher education and more ambitious career goals, younger officers entered the force with expectations for training and skill utilization that their employer could not satisfy. They wanted more police training and vigorously communicated this desire to sympathetic former police officers within the security administration. Disillusioned with what they perceived as deficiencies in crime control instruction, younger officers pressed for its incorporation in future training. The following remark captures the sentiment: "I didn't get the training that I wanted. I'm disappointed with that." Bolstering their enthusiasm for training in the special constable program (16 officers under 40 ) was their belief that the expertise acquired would increase their opportunities for more autonomy, greater prestige, and better pay while at the same time making them increasingly marketable either to a police force or to another security agency.

Two additional factors reinforced the yearning for special constable status. First, younger officers believed that significant publics (police, students, trespassers) were stereotyping them as mere "guards" primarily because they lacked police training and certification. Second, special constable aspirants also perceived themselves as saddled with what Hughes (1958) terms "dirty work." Locking doors, resetting fire alarms, and granting people access to buildings, from these officers' perspective, were trivial and mundane tasks that diverted their energies from the more complex, challenging, and prestigeful crime fighting and order maintenance work of the sort routinely undertaken by their revered reference group - police officers.

Older rank and file officers approaching the end of their careers were unenthusiastic about undertaking additional police-like training and they did not favour such training for their youthful fellows. Firmly committed to the traditional loss prevention and service roles, veterans promoted these skills in the instructional regimen. They saw on-the-job training of newcomers by older veterans as the best means of promoting skill development and viewed with disdain the force's increasing emphasis on crime control over loss prevention and service. 


\section{Mobility}

The rank structure consists of Security Officer, Senior Security Officer, and Security Supervisor. Two horizontal moves are theoretically open to Security Supervisors: Security Investigator and Crime Prevention Officer. The positions of Assistant Director and Director of Security and Parking Services represent the highest ranks.

Not surprisingly, average annual salaries varied by rank: Security Officer $(\$ 26,000)$, Senior Security Officer $(\$ 27,000)$, and Security Supervisor $(\$ 33,000)$. The highest salaries were earned by administrators and averaged $\$ 43,000$. At the time of the study, the force had no formal policy governing merit increases.

Since the force had no clearly defined timetables for advancement, officers were rather in the dark concerning the length of time required at a particular rank before promotion could be expected. There was no formal evaluation of security officers for promotion purposes and seniority, at least in the formal sense, was not a major factor in advancement. Administrators' promotion decisions involved informal subjective assessments of candidates based on some combination of age, seniority, previous training, and experience in policing. In the years immediately preceding the study, the force had upgraded its promotion procedure by utilizing written tests covering various law and security procedures contained in the Standard Operating Procedures manual. Candidates seeking to advance from the lowest rank were formally interviewed by two Security Supervisors and by both Assistant Directors.

At the time of the study, just over one-third (15 of 35) had been promoted at some point in their careers with the force. Thirteen officers who started as Security Officers had advanced one or two steps to become Senior Security Officers or Security Supervisors. Two officers had risen from one administrative post (Security Investigator or Crime Prevention Officer) to a higher one (Assistant Director).

Vertical mobility was influenced by length of employment, age, and changes in leadership. Duration of service varied considerably. Of the 20 officers who had not been promoted, none had served more than five years with the force. Just prior to the study, the security leadership had decided against the use of a formal seniority system as a basis for promotion. This 
approach was rejected because it would have favoured older and more seasoned security-oriented officers who presumably embodied a rather outdated style of security provision that de-emphasized crime control tactics. Believing that more youthful and better-trained officers could more successfully organize the delivery of critical crime control and order maintenance services and that some veterans were either unwilling or unable to perform these crucial tasks, recently hired leaders appointed four younger persons (aged 22-34) to Senior Security Officer and/or Security Supervisor positions. In an effort to create the requisite vacancies for younger officers, senior administration either demoted or transferred four highly experienced veterans.

The greatest dissatisfaction with mobility prospects was communicated by younger personnel. In their bid to advance from the lowest rank, many had been unsuccessful and were frustrated as a consequence. Indicative of this disenchantment are the following comments:

There is no incentive to work here. I don't give a shit anymore.

I'm not going to hang around here for the next 20 years to get promoted to Assistant Director.

In the face of blocked opportunities for advancement, these officers assiduously pushed for the acquisition of special constable status which they regarded as a means of generating a more specialized division of labour along police lines. As one officer put it, "If we go police force, there will be more opportunities to advance."

Both senior managers and lower ranking veterans, unlike younger, recently recruited officers, were more content with their lot. A majority had experienced upward mobility in the past and, being older and nearing the end of their careers, were less fervent about further promotion. Administrators, however, did support the transformation to a special constable force as a strategy for creating more favourable career prospects for the younger officers while at the same time increasing these officers' job satisfaction.

At or about the time that field work was completed, four junior officers were successful in their bid to join police forces. Three moved to the local municipal force and one to a regional agency. In addition to these four, another officer accepted a position with a university force that 
employed (and trained) special constables. Before their appointments with campus security, all five had aspired to become police officers. In not one case was their period of employment with the university force greater than four years.

\section{Job Content}

All four major police and security functions - crime control, order maintenance, service, and loss prevention - were carried out to varying degrees by campus personnel. Preventative patrolling and responding to criminal code infractions through the apprehension and arrest of suspects are crime control responsibilities with which the force is charged. Central to order maintenance is the control of disorderly conduct (group protests, public drunkenness, disruptive behaviour) that might evolve into criminal offenses. Providing directions, searching for missing persons, and escorting people to hospitals are functions that involve service delivery (Griffiths \& Verdun-Jones, 1994). Loss prevention involves the guarding of people, assets, and information from accidents, natural disasters, and carelessness as well as from crime. Its goal is to preclude physical, monetary, and emotional losses incurred by clients or employers (Timm \& Christian, 1991).

Routine patrols designed to deter or detect offending comprised security officers' principal crime control activity during the period of observation. Officers rarely carried out investigations and when they did so these were of the preliminary sort and involved minor property offenses - mostly theft ( 6 occurrences). Arrests were very infrequent and were confined largely to incidents involving trespassing.

The control of parking and traffic comprised the most frequent order maintenance initiative. During the period of observation, there were 47 cases requiring traffic enforcement, warnings, information processing, or accident investigation. Only rarely did the maintenance of order call for responding to disturbances involving verbal confrontations ( 7 occurrences) or physical aggression (1 case). Preliminary investigations of suspicious persons ( 8 incidents) comprised the remainder of cases. Aside from routine patrol, service provision such as providing directions, delivering mail, unlocking classrooms, receiving recovered property, 
searching for persons reported missing, transporting visitors, and doing general maintenance (e.g., investigating reported water and gas leaks) comprised almost all of the force's time and energy. Locking facilities (38 instances), regulating access to buildings and offices (16 cases), transporting monies to and from commercial establishments and offices (16 times), and answering fire alarms (5 occurrences) were the principal loss prevention tasks performed

\section{Occupational Segmentation}

The findings from this case study indicate that rank and file officers comprised two distinct groups, each with unique demographic characteristics and work orientations. The security-oriented group $(n=9)$ was comprised of older, less-educated officers approaching retirement whose previous police or security experience had been acquired in the distant past and whose tenure with the force had been lengthy ( 8 officers -11 or more years). The police-oriented group $(n=21)$ was comprised of younger and better-educated officers eager for advancement. Their length of service was considerably shorter ( 20 officers -4 or fewer years).

The longstanding prevention role traditionally associated with private security work comprised the primary work emphasis of the securityoriented group. Its members enthusiastically initiated and took pride in both loss prevention and service tasks. The higher risk activities associated with order maintenance and especially crime control (arrests), however, were both depreciated and avoided. Traffic control comprised the main order maintenance work carried out and valued by this group. The central mission of security-oriented officers' routine patrols was to identify security hazards (unlocked doors) with the potential to generate losses. While they perceived themselves as especially capable when it came to attending to fire alarms, lending general assistance, responding to access calls, and locking buildings, they avoided as much as possible actions aimed at calming disturbances or making arrests. Veterans valued loss prevention and service work because they believed that the university and its clients (students, faculty, visitors) were best served by these functions. The words of one officer nicely illustrate this group's positive orientation to service provision: 
My job is to serve members of the community and to open doors for professors as required. My duty is to provide access for [them] to do [their] job. I do this willingly.

For the police-oriented segment, on the other hand, the opportunity to carry out the riskier and potentially more dangerous initiatives associated with order maintenance and especially crime control was embraced with enthusiasm. However, since little serious crime took place on campus, police-oriented officers viewed order maintenance work (excluding parking and traffic enforcement) as both adventuresome and satisfying. When they were called upon to perform loss prevention and service work, as was routinely the case, they did so reluctantly and interpreted it as "dirty work" that diverted time and attention from their preferred missions - crime fighting and order maintenance.

Police-oriented officers' routine patrols were centred entirely on preventing or detecting personal and property crimes (assaults, break and enters, and vandalism) and identifying trespassers. The very few arrests witnessed during the 5 months of field work ( 2 for trespassing, 1 for theft under $\$ 1000$ ) were made exclusively by members of the police-oriented group. The remarks of one officer captured the positive orientation to this type of work:

I like to see justice served and to protect and serve the public.

It's very rewarding to make an arrest and to serve someone.

You can be a positive role model on people by using your uniform and power. I have arrested a 14 year old and called in the police. I scared the hell out of him and he probably wouldn't do it [the prohibited act] again.

Partly as a response to new recruitment requirements instituted by recently hired security administrators with police backgrounds, the police-oriented group was expanding in numbers while the security-oriented group was shrinking. As a result, the police-oriented crime control approach was becoming more dominant within the security force.

As already noted, follow-up data indicate that several of those heavily committed to the crime fighting role were ultimately successful in their bid to become police officers. For the police-oriented who remained behind, there was a strong commitment to converting security work into 
their desired vision by stressing real policing through crime control. Ironically, this emphasis on crime control contradicted the university's officially articulated service excellence orientation. It is also somewhat paradoxical that police-oriented officers equated police work with crime fighting despite the fact that this image differs starkly from the daily reality of public policing (Ericson, 1982; Shearing, 1984; Wilson, 1968).

The security and police-oriented segments displayed moderately antagonistic views of each other. The security-oriented group perceived the officers in the police-oriented group both as unskilled at loss prevention and service and as irresponsible for depreciating these initiatives. They also believed that the police-oriented segment's aggressive attitude, inept communication, and willingness to use coercion combined to undermine loss prevention and service, to tarnish the image of the force, and to fuel complaints from the public. In particular, the security-oriented group was critical of police-oriented officers' heartfelt desires for greater law enforcement authority (special constable status) and for the concomitant acquisition of the hardware associated with crime control (handcuffs). For their part, the police-oriented group viewed their security-oriented counterparts as either reluctant or inept in the performance of order maintenance and crime control tasks. Of special significance was their concern that older security-oriented officers could not deliver safe and effective backup in an emergency.

Members of the competing segments also expressed divergent opinions concerning their major audiences (students, faculty, the public). Police-oriented officers saw themselves working in an unstable environment with little public support. They attributed this lack of support to their being associated with mundane work (loss prevention and service) and to their lack of peace officer status and powers. From their perspective, public respect for their work as law enforcement agents and as peacekeepers was contingent on their acquisition of police powers in the form of special constable status. As a police-oriented officer explained:

Security officers are not respected by people because they have no powers. If you're a security guard, you've got no power. The public respects the police because they know that the police have more power. Security needs more police-like power. 
Members of the security-oriented group, however, disagreed. They believed that loss prevention and service functions were viewed in a positive light by the university community. As one officer explained, "You're part of the community. The students and faculty don't think of you as inferior."

\section{Conclusion}

University administrators and policy planners require a clear understanding of the nature of victimization and fear of crime if they are to develop cost effective resolutions to these problems. Nonetheless, while Canadian campuses vary enormously on crime risk dimensions such as size, composition, and location, almost no rigorous studies of campus crime, fear, or policing have been conducted. Neither the findings from the Simon Fraser victimization survey nor those from the present study of campus policing can be generalized to other Canadian campuses. American studies, while somewhat larger in number, are of limited relevance to the Canadian situation since the two countries differ significantly with respect to their crime problems (Gomme, 1993). The picture that emerges from the limited research suggests that campus crime is rare and non-serious, that fear of crime is greater than warranted, and that campus police, organizationally and individually, have adopted a professional model of enforcement that stresses the primacy of crime control both formally and informally through recruitment, training, socialization, and promotion strategies. These preliminary findings raise questions concerning the degree to which the objectives and actions of campus police are appropriate and cost effective responses to universities' security requirements and whether shifts in priorities and practices are called for. Among important points at issue are the proper goals for campus security agencies, the best strategies for the achievement of those goals, and the evaluation of programs and policies to determine what organizational forms and procedural modalities work best in particular settings.

Existing evidence calls into question the advisability of formally or informally promoting crime control (deterrence, investigation, and 
apprehension) as the primary goal of security for at least two reasons. First, the literature reviewed and the findings presented in this paper suggest that campus crime is infrequent and rarely involves personal injury. Second, a great deal of criminological research has challenged the utility of the crime control and professional models of policing for communities more generally. Based on these observations, some analysts (Bordner \& Petersen, 1983; Jacobs \& O’Meara, 1980; Peak, 1995) suggest that strategies such as hiring additional officers, reorganizing patrols, expanding security officers' powers, and augmenting rapid response technologies are ineffective at reducing victimization and may actually increase fear. Citizens interpret more police and intensified policing as occurring out of necessity and for good reason; where there are police, the thinking goes, there must be a serious crime problem.

Some American research paints a picture of security operations similar to that produced by the present study - officers suffer from what Peak (1995) and Heinsler, Kleinman, and Stenross (1990) refer to as an "identity problem." Seeing themselves cast in pejorative terms such as "second rate police," "guards," and "door shakers," agencies and their officers have sought to professionalize (Peak, 1995). In so doing, they have adopted the paramilitary organization, hierarchical rank and authority structure, specialization, and emphasis on the crime control mandate that characterize Canada's public police agencies. Entry standards and in-service training have risen and become more police-like. University forces have increasingly acquired police training, equipment, and accreditation all of which have reflected the crime control emphasis inherent in the professional police model. Members of many Canadian campus forces have attained the status of special constables. Officers with special constable status enjoy expanded powers to arrest on suspicion, to issue provincial offense tickets, to have legitimate access to the use of force and restraining devices, and to engage in searches and seizures. These powers, of course, are in addition to those accorded to private property owners (or their agents) under the Trespass to Property Act, a statute that enables security officers patrolling privately owned premises to intrude upon individuals' privacy to an even greater extent than that accorded to public police officials. As Shearing (1982) observes with regard to 
private policing more generally, the Trespass to Property Act provides security officers with more than sufficient power and authority to address the relatively few situations likely to represent order maintenance or crime control problems of a potentially serious nature.

Several problems worthy of additional research confront university officials as they consider ways and means of improving the efficiency of security service delivery. First, crime control initiatives frequently do not coincide perfectly with university objectives. Arresting and detaining students and initiating proceedings which might result in their acquiring a criminal record are often not desired courses of action. On the other hand, the adverse impacts on commitment and morale brought about by university officials constraining security officers' professional judgments and authority may undermine the overall effectiveness of that campus agency. Second, universities routinely require that security forces perform low level service tasks (e.g., access control, lock-ups, parking control) that many officers define as "dirty work" and a distraction from real policing. Dirty work such as locking doors and windows and responding to calls for access, however, is central to universities meeting their loss prevention and service missions. Officers shunning what they consider dirty work may expose the university to risk both by performing loss prevention tasks unsatisfactorily and by responding to minor crime legalistically with arrests. Third, given the community relations problems that often follow from the exercise of police powers, the operations and effectiveness of security agencies with special constable status should be compared to those without such powers.

Finally, it is not without irony that police forces themselves have come to the realization that the pursuit of the crime fighting goal has met with limited success. Police agencies, under the rubric of community policing, are currently attempting to alter the organization of policing in order that general service provision, crime prevention, and peacekeeping supersede crime fighting as primary organizational objectives (Moore, 1992). As noted police scholar Lawrence Sherman (1995) has pointed out, the officially stated aims traditionally associated with private security - loss prevention and service - closely resemble the program of reform embodied in the notion of community policing. In keeping with 
their tradition of emulating municipal police, campus security agencies are officially forsaking their adherence to the professional model of policing and are increasingly embracing the "new" community policing model (Lanier, 1995). In essence, campus police are now attempting to adopt the security-oriented prevention and service model that many believe has represented their mandate for years.

While the community policing approach is being promoted officially by municipal departments, research has questioned the degree to which its tenets are fully embraced by rank and file police officers. As many studies have shown, a gap separates the reality from the rhetoric of community policing (Klockars, 1988; Leighton, 1991; Walker, 1992). As in public policing, campus security work may be characterized by a similar chasm that divides the actual from the articulated (Ishwaran, 1994). Evidence from this study and from some American research suggests that a powerful and expanding segment within university security is strongly committed to the professional model of policing and is paying lip service to translating loss prevention and service provision into concerted action despite the fact that these objectives form the basis of agencies' formally stated goals (Lanier, 1995; Peak, 1995).

The professional model, unsuitable as it is for routine policing, is even more unsuitable for the practice of campus security. If the additional research called for in this paper confirms that Canadian university security forces generally adhere to this model in practice, several options might be explored as means of hastening the transition to a more effective community-oriented security model. First, pre-service and in-service training should be designed to curb the implementation of a crime control style of policing which is inconsistent with universities' service and loss prevention objectives. Rather, training in human relations, access control, property law, the basic mission of the university as a professional organization, and the bureaucratic nature of university decisionmaking should be markedly intensified. There are indications that a newly created professional association, the Ontario Association of College and University Security Administrators (OACUSA), is planning training programs precisely of this sort (Canadian Security, August/September 1995). 
Second, recruitment strategies need to be re-examined. Current policies favouring the hiring of former police officers into management positions combined with assiduous efforts to recruit young officers who are security or law enforcement college graduates, who have police experience, and who ultimately wish to become police officers may be counterproductive in that they reinforce the professional as opposed to the community-based approach. Recruitment initiatives should be broadened to acquire personnel whose characteristics and orientations match the service and prevention priorities inherent in the community-based approach. For example, university forces might recruit salaried and volunteer personnel without prior police training and experience. They might also transfer employees with knowledge and skills acquired in other university departments such as physical plant, maintenance, and parking into security.

Finally, efforts should be undertaken to more fully integrate the university community into the prevention and service missions of the security force. Such initiatives might include establishing or expanding security advisory committees comprised of representatives from the university at large, broadening and strengthening adjudicative bodies charged with informal dispute resolution, expanding paid and unpaid student security personnel involved in escort and surveillance activities, and encouraging greater faculty and student awareness of crime prevention techniques through personal communication, education and media releases.

\section{References}

Adler, F., Mueller, G., \& Laufer, W. (1996). Criminal justice: The core. Toronto, ON: McGraw-Hill Company.

Bausell, C., Bausell B., \& Siegel, D. (1991). The links among drugs, alcohol and campus crime. Towson, MD: Campus Violence Prevention Centre, Towson State University.

Belknap, J., \& Erez, E. (1995). The victimization of women on college campuses: Courtship violence, date rape and sexual harassment. In B.S. Fisher, \& J.J. Sloan (eds.), Campus crime: Legal, social and policy perspectives, (pp. 156-178). Springfield, IL: Charles C. Thomas. 
Bordner, D.C., \& Petersen, D.M. (1983). Campus policing: The nature of university work. Lanham, MD: University Press of America.

Brantingham, P.J., \& Brantingham, P.L. (1994). Surveying campus crime: What can be done to reduce crime and fear? Security Journal, 5(3), 160-171.

Brantingham, P.J., Brantingham, P.L, \& Seagrave, J. (1995). Crime and fear of crime at a Canadian university. In B.S. Fisher, \& J.J. Sloan (eds.), Campus crime: Legal, social and policy perspectives, (pp. 123-155). Springfield, IL: Charles C. Thomas.

Bromly, M.L. (1992). Campus and community crime rate comparisons: A statewide study. Journal of Security Administration, 15(2), 519-531.

Bromly, M.L. (1995). Securing the campus: Political and economic factors affecting decision makers. In B.S. Fisher, \& J.J. Sloan (eds.), Campus crime: Legal, social and policy perspectives, (pp. 214-227). Springfield, IL: Charles C. Thomas.

Canadian Security. (1995, August/September). Campus security officers in new program presented this summer at Humber College. 11.

Dekeseredy, W.S., \& Kelly, K. (1993). The incidence and prevalence of woman abuse in Canadian university and college dating relationships. Canadian Journal of Sociology, 18(2), 137-159.

Dekeseredy, W.S., \& Kelly, K. (1995). Sexual abuse in Canadian university and college dating relationships: The contribution of male peer support. Journal of Family Violence, 10(1), 41-53.

Donham, P.B. (January, 1995). Thought control goes to college: Do fairness and due process still matter on Canadian campuses? Reader's Digest, 109-114.

Ericson, R. (1982). Reproducing order: A study of police patrol work. Toronto, ON: University of Toronto Press.

Fernandez, A., \& Lizotte, A. (1995). An analysis of the relationship between campus crime and community crime: Reciprocal effects? In B.S. Fisher, \& J.J. Sloan (eds.), Campus crime: Legal, social and policy perspectives, (pp. 79-102). Springfield, IL: Charles C. Thomas.

Fisher, B.S., \& Nasar, J.L. (1992). Students fear of crime and its relation to physical features of the campus. Journal of Security Administration, 15(2), 65-75.

Fisher, B.S., \& Sloan, J.J. (1993). University responses to the Campus Security Act of 1990: Evaluating programs designed to reduce campus crime. Journal of Security Adminsitration, 16(1), 67-69.

Fox, B.J. (1993). On violent men and female victims: A comment on Dekeseredy. Canadian Journal of Sociology, 18, 320-324. 
Freedman, D.J., \& Stenning, P.C. (1977). Private security and the law in Canada.

Toronto, ON: Centre of Criminology, University of Toronto.

Gartner, R. (1993). Studying woman abuse: A comment on Dekeseredy.

Canadian Journal of Sociology, 18, 314-319.

Gomme, I.M. (1993). The shadow line: Deviance and crime in Canada.

Toronto, ON: Harcourt Brace Jovanovich.

Griffiths, C.T., \& Verdun-Jones, S. (1994). Canadian criminal justice. Toronto,

ON: Harcourt Brace \& Company.

Heinsler, J., Kleinman, S., \& Stenross, B. (1990). Making work matter:

Satisfied detectives and dissatisfied campus police. Qualitative Sociology, $13(3), 215-250$.

Hirschi, T., \& Gottfredson, M. (1983). Age and the explanation of crime. American Journal of Sociology, 89, 551-584.

Hughes, E.C. (1958). Men and their work. Glencoe, IL: Free Press.

Ishwaran, S. (1994). Community-based policing: The rhetoric of community participation. In K.R.E. McCormick (ed.), Carceral contexts: Readings in control, (pp. 179-192). Toronto, ON: Canadian Scholars' Press.

Jacobs, J.B., \& O'Meara, V.A. (1980). Security forces and the transformation of the American university. College and University, 31(2), 283-297.

Johnson, H. (1996). Dangerous domains: Violence against women in Canada. Toronto, ON: Nelson Canada.

Klockars, C.B. (1988). The rhetoric of community policing. In J. Greene \& S. Mastrofski (eds.), Community policing: Rhetoric or reality, (pp. 239-258). New York, NY: Praeger.

Knott, J. (1993, December). Making the grade in campus security. Security Sales, 27-36.

Lanier, M.M. (1995). Community policing on university campuses: Tradition, practice, and outlook. In B.S. Fisher, \& J.J. Sloan (eds.), Campus crime: Legal, social and policy perspectives, (pp. 246-263). Springfield, IL: Charles C. Thomas.

Lederman, D. (1993, January). Colleges report 7,500 violent crimes on their campuses in first annual statements required under federal law. The Chronicle of Higher Education, A32-43.

Leighton, B.N. (1991). Visions of community policing: Rhetoric and reality in Canada. Canadian Journal of Criminology, 33, 495-522.

Matthews, A. (1993, March). The campus crime war. The New York Times Magazine, 38-47. 
Moore, M.H. (1992). Problem solving and community policing. In M. Tonry \& N. Morris (eds.), Modern policing, (pp. 99-158). Chicago, IL: University of Chicago Press.

Moriarty, L.J., \& Pelfrey, W.V. (1996). Exploring explanations for campus crime: Examining internal and external factors. Journal of Contemporary Criminal Justice, 12(1), 108-119.

Morin, D. (1990, May). Need to improve security awareness. University Affairs, 10. Murphy, C., \& Clairmont, D. (1990). Rural attitudes and perceptions of crime, policing and victimization: Preliminary findings from a survey of rural Nova Scotians. Unpublished paper. Halifax, NS: Atlantic Institute of Criminology, Dalhousie University.

Ordovensky, P. (1990). Hour by hour, campus crime toll mounts. Louisville, KY: USA Today Crime Series Reprints.

Peak, K.J. (1995). The professionalization of campus law enforcement: Comparing campus and municipal law enforcement agencies. In B.S. Fisher, \& J.J. Sloan (eds.), Campus crime: Legal, social and policy perspectives, (pp. 214-227). Springfield, IL: Charles C. Thomas.

Rajacich, D., Fawdry, M.K., \& Berry, M.L. (1992). An institutional response to date rape. The Canadian Journal of Higher Education, 22(2), 41-59.

Reiss, A.J. Jr. (1985). Why are communities important in understanding crime? In A.J. Reiss Jr. \& M. Tonry (eds.), Communities and crime, (pp. 1-34). Chicago, IL: University of Chicago Press.

Richards, G.E. (1996). The security survey: Creating a proactive foundation for campus crime prevention. Journal of Contemporary Criminal Justice, $12(1), 45-53$.

Sacco, V.F., \& Johnson, H. (1990). Patterns of criminal victimization in Canada. Ottawa, ON: Ministry of Supply and Services.

Sampson, R.J. (1995). The community. In J.Q. Wilson \& J. Petersilia (eds.), Crime, (pp. 193-216). San Francisco, CA: Institute for Contemporary Studies.

Shearing, C.D. (1984). Dial-a-cop: A study of police mobilisation. Toronto, ON: Centre of Criminology, University of Toronto.

Shearing, C.D. (1982). Private security in Canada. In C.L. Boydell \& I.A. Connidis (eds.), The Canadian criminal justice system, (pp. 248-265). Toronto, ON: Holt, Rinehart and Winston of Canada Limited.

Sherman, L.W. (1995). The police. In J.Q. Wilson \& J. Petersilia (eds.), Crime, (pp. 193-216). San Francisco, CA: Institute for Contemporary Studies.

Siegel, D., \& Raymond, C. (1992). An ecological approach to violent crime on campus. Journal of Security Administration, 15(2), 19-29. 
Skogan, W.G. (1990). Disorder and decline: Crime and the spiral of decay in American neighbourhoods. New York, NY: Free Press.

Sloan, J. (1992). Origins and evolution of the campus police. American Journal of Police, 11(2), 86-101.

Sloan, J. (1994). The correlates of campus crime: An analysis of reported crimes on university campuses. Journal of Criminal Justice, 22(1), 51-62.

Sloan, J.J., \& Fisher, B.S. (1995). Campus crime: Legal, social and policy contexts. In B.S. Fisher \& J.J. Sloan (eds.), Campus crime: Legal, social, and policy perspectives, (pp. 3-22). Springfield, IL: Charles C. Thomas.

Sloan J.J., Fisher, B.S., \& Wilkins, D.L. (1996). Reducing perceived risk and fear of vicitimization on campus: A panel study of faculty members, staff and students. Journal of Contemporary Criminal Justice, 12(1), 81-107.

Smith, M.C. (1988). Coping with crime on campus. New York, NY: Macmillan. Smith, M.C. (1995). Vexatious victims of campus crime. In B.S. Fisher \& J.J. Sloan (eds.), Campus crime: Legal, social, and policy perspectives, (pp. 25-37). Springfield, IL: Charles C. Thomas.

Smith, M.C., \& Fossey, R. (1995). Crime on campus: Legal issues and campus administration. Phoenix, AZ: The Oryx Press.

Statistics Canada. (1993). General social survey. Ottawa, ON: Microdata file.

Steenbarger, B., \& Zimmer, C. (1992). Violence on campus: The changing face of college health. Journal of Amercian Health, 40(4), 147-148.

Stormer, D.E., \& Senarath, D.T. (1992). The truth about campus crime. An analysis of campus crime reports for three years in Pennsylvania. The Campus Law Enforcement Journal, 22(4), 28-32.

Timm, H.W., \& Christian, K. (1991). Introduction to private security. Pacific Grove, CA: Brooks/Cole Publishing.

University Affairs. (1995, December). Tracking violent students: How to balance privacy and safety, p. 19.

University Affairs. (1992, March). Ontario launches date rape awareness, p. 15.

University Affairs. (1992, April). Faculty member dismissed for sexual harassment, p. 22.

Vito, G.F., \& Holmes, R.M. (1994). Criminology: Theory, research and policy. Belmont, CA: Wadsworth Publishing Company.

Walker, S. (1992). The police in America. New York: McGraw Hill.

Wilson, J.Q. (1968). Varieties of police behaviour: The management of law and order in eight communities. Cambridge, MA: Harvard University Press.

Wilson, J.Q., \& Kelling, G.L. (1982). Broken windows. Atlantic Monthly, 127, 29-38. 